Article

\title{
Ir-Based Bimetallic Catalysts for Hydrogen Production through Glycerol Aqueous-Phase Reforming
}

\author{
Francisco Espinosa-Moreno ${ }^{1}$, Putrakumar Balla ${ }^{2}$, Wenjie Shen ${ }^{2}$, \\ Juan C. Chavarria-Hernandez ${ }^{1, *} *$, Miguel Ruiz-Gómez ${ }^{3}(\mathbb{D})$ and Saúl Tlecuitl-Beristain ${ }^{4}$ \\ 1 Centro de Investigación Científica de Yucatán, Parque Científico y Tecnológico de Yucatán, \\ Carretera Sierra Papacal-Chuburna Puerto, km 5. Sierra Papacal, 97302 Mérida, Yucatán, Mexico; \\ xavier.emf@gmail.com \\ 2 State Key Laboratory of Catalysis, Dalian Institute of Chemical Physics, Chinese Academy of Sciences, \\ 457-Zhong Shan Road, Dalian 116023, China; putrakumarb@dicp.ac.cn (P.B.); shen98@dicp.ac.cn (W.S.) \\ 3 CONACYT-Departamento de Física Aplicada, CONACYT-CINVESTAV-IPN, 97310 Mérida, Yucatán, \\ Mexico; miguel.ruiz@cinvestav.mx \\ 4 Ingeniería en Biotecnología, Universidad Politécnica de Tlaxcala, San Pedro Xalcatzinco, 90180 Tepeyanco, \\ Tlaxcala, Mexico; saul.tlecuitl@uptlax.edu.mx \\ * Correspondence: jc.ch@cicy.mx; Tel.: +52-(999)930-0760 (ext. 1206)
}

Received: 27 October 2018; Accepted: 27 November 2018; Published: 3 December 2018

check for updates

\begin{abstract}
Iridium, Iridium-Nickel and Iridium-Copper catalysts were prepared by incipient wetness impregnation and evaluated in the aqueous-phase reforming of glycerol using $\mathrm{La}_{2} \mathrm{O}_{3}$ or $\mathrm{CeO}_{2}$ as supports. The catalysts were characterized by $\mathrm{N}_{2}$ physisorption, $\mathrm{XRD}, \mathrm{H}_{2}-\mathrm{TPR}, \mathrm{XPS}$, and EDS. The reactions were carried out in a fixed bed reactor feeding a solution of glycerol (10 wt \%) in water, at $270{ }^{\circ} \mathrm{C}$ and 58 bar. All IrNi catalysts showed higher activity than Ir and IrCu, and in general, $\mathrm{La}_{2} \mathrm{O}_{3}$ catalysts showed a better performance when compared to $\mathrm{CeO}_{2}$ catalysts. The highest hydrogen production yield was reached by bimetallic IrNi catalysts with over $250 \mu \mathrm{mol} \mathrm{min}{ }^{-1} \mathrm{~g}_{\text {cat }}{ }^{-1}$ for $\mathrm{La}_{2} \mathrm{O}_{3}$ and $150 \mu \mathrm{mol} \mathrm{min}{ }^{-1} \mathrm{~g}_{\text {cat }}{ }^{-1}$ for $\mathrm{CeO}_{2}$.
\end{abstract}

Keywords: iridium; glycerol; aqueous-phase reforming; hydrogen production

\section{Introduction}

Fossil fuels have been the main energy source used to satisfy society's needs since 1950, with a contribution of $64 \%$ of the global primary energy [1] and with $86 \%$ of global contribution registered in 2015 [2]. Issues related to the usage of fossil fuels such as depletion of reserves, rising of polluting gases and climate change have been addressed elsewhere [3-7]. Renewable energy is an alternative to the use of hydrocarbons. Among renewable energy types, hydrogen technology is a promising one. Hydrogen is not considered as an energy source but an energy carrier, and it can be harnessed for direct energy production through its use in fuel cells [8-11]. A drawback for hydrogen is that it must be obtained or produced from other sources such as water or biomass, for instance. Therefore, several methods have been studied for obtaining hydrogen, such as pyrolysis, electrolysis, biochemical processes with bacteria and algae, and reforming processes (using alcohols, oils) [12-15]. Among the different reforming processes, aqueous-phase reforming (APR) is a promising option. In APR, a substrate reacts in the presence of a catalyst at low-to-medium temperatures, splitting molecules and producing hydrogen, among other compounds. APR was investigated for the first time in 2002 by Dumesic and his workgroup, and since then they have explained the details on thermodynamics and the kinetics of the process [16]. Oxygenated hydrocarbons, such as alcohols have 
been studied as APR substrate [17-20]. Otherwise, glycerol is a biodiesel production byproduct, about $10 \mathrm{wt} \%$ of fats and oils used in biodiesel production turn to glycerol. Therefore, glycerol has gained interest as it will be more available with the increase of the biodiesel industry. Despite its multiple uses in areas such as in medicine or the cosmetic industry, the market is limited, and then it is necessary to explore for potential additional uses that result in an added value for glycerol $[20,21]$. Iridium has been studied in the APR of methanol [22,23], ethylene glycol [24], and ethanol [25], and more extensively studied as a catalyst for other processes [26-33]. However, as far as the authors know, Iridium has never been analyzed using glycerol as a raw material under APR conditions. Iridium has shown high activity and $\mathrm{H}_{2}$ selectivity when using ethanol [25]. Nevertheless, a drawback for the use of Ir in APR is the low activity in the water-gas shift reaction, a fundamental step in obtaining higher $\mathrm{H}_{2}$ yields [24]. Therefore, it is necessary to conduct a study focused on overcoming that barrier to maximize the formation of $\mathrm{H}_{2}$. Nickel has high activity on $\mathrm{C}-\mathrm{C}$ bonds cleavage, although it also shows activity in the methanation process, which consumes hydrogen. On the other hand, $\mathrm{Cu}$ has shown significant activity mainly for the water-gas shift reaction. Therefore, in this work, the use of $\mathrm{Ni}$ and $\mathrm{Cu}$ as second metals in Iridium catalysts to produce a synergetic effects for hydrogen are proposed.

\section{Results and Discussion}

\subsection{Catalysts Characterization}

\subsubsection{Physical Properties}

Table 1 summarizes the textural properties of catalysts after calcination. The specific surface area of $\mathrm{La}_{2} \mathrm{O}_{3}$-supported catalysts is slightly bigger than $\mathrm{CeO}_{2}$ catalysts. $\mathrm{La}_{2} \mathrm{O}_{3}$ catalysts have almost twice the pore volume than $\mathrm{CeO}_{2}$ catalysts, causing a better metal dispersion.

Table 1. Textural properties of catalysts and supports.

\begin{tabular}{cccc}
\hline Catalyst & $\mathbf{S}_{\mathbf{B E T}} / \mathbf{m}^{\mathbf{2}} \mathbf{g}^{-\mathbf{1}}$ & $\mathbf{V}_{\mathbf{p}} / \mathbf{c m}^{\mathbf{3}} \mathbf{g}^{\mathbf{- 1}}$ & Pore Size (Average Radius/Å) \\
\hline $\mathrm{La}_{2} \mathrm{O}_{3}$ & $9.1 \pm 0.5$ & $(2.5 \pm 0.3) \times 10^{-2}$ & $55.4 \pm 0.1$ \\
$\mathrm{Ir} / \mathrm{La}_{2} \mathrm{O}_{3}$ & $10.2 \pm 0.6$ & $(2.2 \pm 0.2) \times 10^{-2}$ & $42.5 \pm 0.1$ \\
$\mathrm{IrCu} / \mathrm{La}_{2} \mathrm{O}_{3}$ & $6.7 \pm 0.4$ & $(1.3 \pm 0.1) \times 10^{-2}$ & $39.2 \pm 0.1$ \\
$\mathrm{IrNi} / \mathrm{La}_{2} \mathrm{O}_{3}$ & $10.1 \pm 0.6$ & $(2.4 \pm 0.3) \times 10^{-2}$ & $47.0 \pm 0.1$ \\
$\mathrm{CeO}_{2}$ & $7.7 \pm 0.5$ & $(2.8 \pm 0.3) \times 10^{-2}$ & $67.8 \pm 0.1$ \\
$\mathrm{Ir} / \mathrm{CeO}_{2}$ & $4.2 \pm 0.2$ & $(6.7 \pm 0.7) \times 10^{-3}$ & $32.1 \pm 0.2$ \\
$\mathrm{IrCu} / \mathrm{CeO}_{2}$ & $5.3 \pm 0.3$ & $(7.9 \pm 0.8) \times 10^{-3}$ & $29.8 \pm 0.2$ \\
$\mathrm{IrNi} / \mathrm{CeO}_{2}$ & $4.8 \pm 0.3$ & $(8.5 \pm 0.9) \times 10^{-3}$ & $35.7 \pm 0.2$ \\
\hline
\end{tabular}

$\mathrm{La}_{2} \mathrm{O}_{3}$ is a hygroscopic material that changes its phase by exposure in air forming $\mathrm{La}(\mathrm{OH})_{3}$ and $\mathrm{La}_{2} \mathrm{O}_{2} \mathrm{CO}_{3}$ [34]. Despite the presence of other phases, catalysts with that support will be named as $\mathrm{La}_{2} \mathrm{O}_{3}$ for simplicity. For $\mathrm{La}_{2} \mathrm{O}_{3}$ catalysts, there is a small surface area increase with metal addition. It has been seen that an increase in the catalyst's surface area can be related to the diffusion of metal species in support and formation of new pores as proposed by Said et al. [35]. For this material, increase in the surface area may occur due to the formation of species such as $\mathrm{NiO}$ and $\mathrm{La}_{2} \mathrm{NiO}_{4}$ as exposed by TPR results presented in Section 2.1.5. Thyssen et al. [36] also reported surface area increments for $\mathrm{La}_{2} \mathrm{NiO}_{4}$ after incorporating Ni. For $\mathrm{CeO}_{2}$ support, the addition of metals caused a specific surface area decrease and reduced pore volume by one order of magnitude. 


\subsubsection{X-ray Diffraction}

XRD pattern for $\mathrm{Ir} / \mathrm{CeO}_{2}$ is presented in Figure $1 . \mathrm{CeO}_{2}$ diffraction peaks can be clearly seen, whereas for Ir, only one diffraction peak at around $34.5^{\circ}$ was identified (Figure 1 inset), corresponding to $\mathrm{IrO}_{2}$. It may be due to the low concentration and high dispersion of the metal on the support. This result was similar to those obtained with $\mathrm{Ni}$ and $\mathrm{Cu}$ as shown in Figures 2 and 3, respectively, where metal oxides can be seen in the insets with a logarithmic scale.

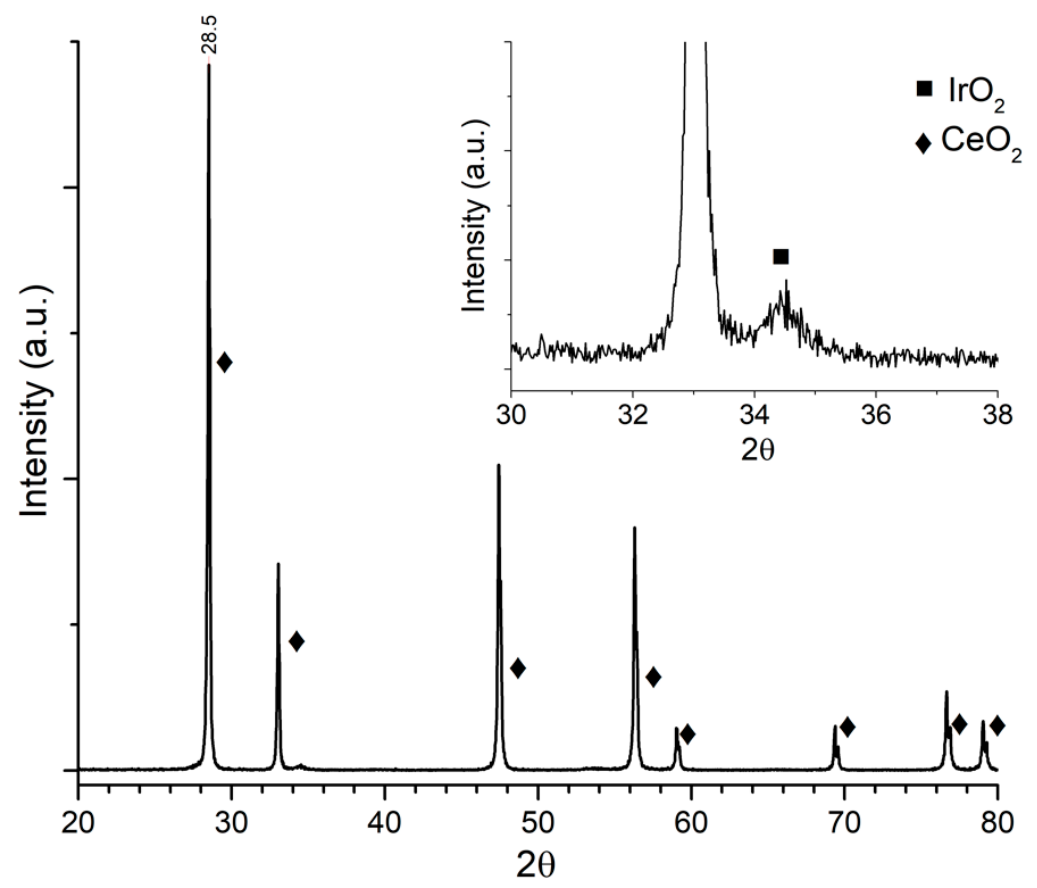

Figure 1. Ir $/ \mathrm{CeO}_{2}$ diffraction pattern.

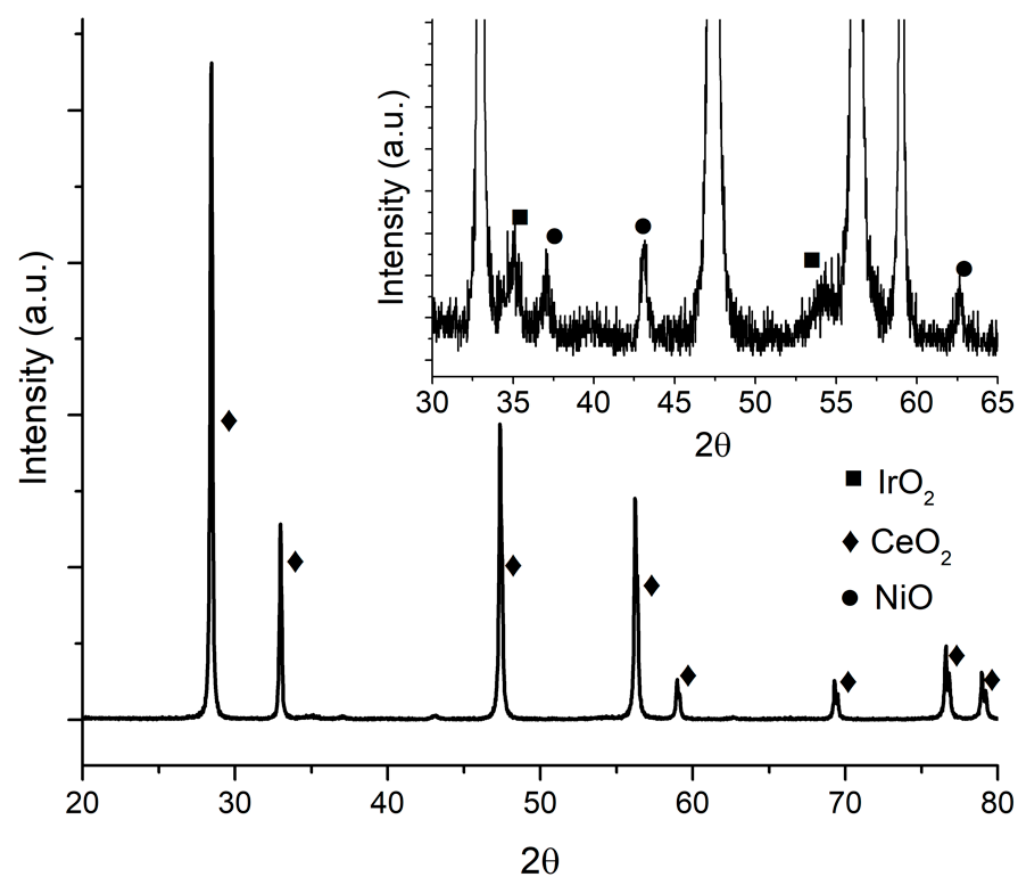

Figure 2. $\mathrm{IrNi} / \mathrm{CeO}_{2}$ diffraction pattern. 


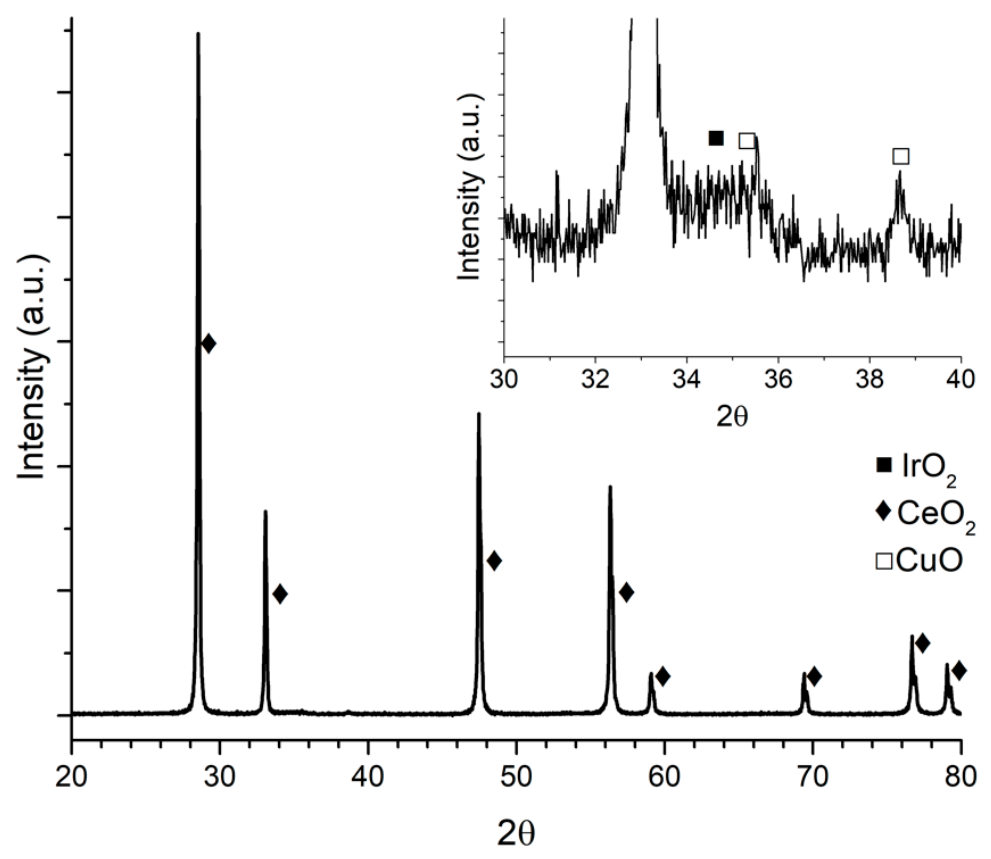

Figure 3. $\mathrm{IrCu} / \mathrm{CeO}_{2}$ diffraction pattern.

In the inset graph in Figure 2, besides $\mathrm{IrO}_{2}$ diffraction peaks at 34.7 and $54.20^{\circ}, \mathrm{NiO}$ peaks at $37.1^{\circ}$, $43.03^{\circ}$, and $62.6^{\circ}$ are shown. In the inset graph in Figure 3, peaks at $35.5^{\circ}$ and $38.6^{\circ}$ belong to $\mathrm{CuO}$.

Figure 4 shows the XRD patterns of the $\mathrm{La}_{2} \mathrm{O}_{3}$ supported catalysts. Due to the hygroscopic nature of the $\mathrm{La}_{2} \mathrm{O}_{3}$, the diffraction patterns shifted towards $\mathrm{La}(\mathrm{OH})_{3}$ and $\mathrm{La}_{2} \mathrm{O}_{2} \mathrm{CO}_{3}$, and it occurred because of exposure of the samples to the atmosphere previously or during characterization. Besides, $\mathrm{La}_{2} \mathrm{O}_{3}$-supported catalysts showed only one peak corresponding to $\mathrm{IrO}_{2}$ diffraction patterns of the supported metals, and it may be due to equipment sensibility, due to good dispersion of the metals throughout the support and possible overlapping of La compound patterns with the rest of the Ir peaks.

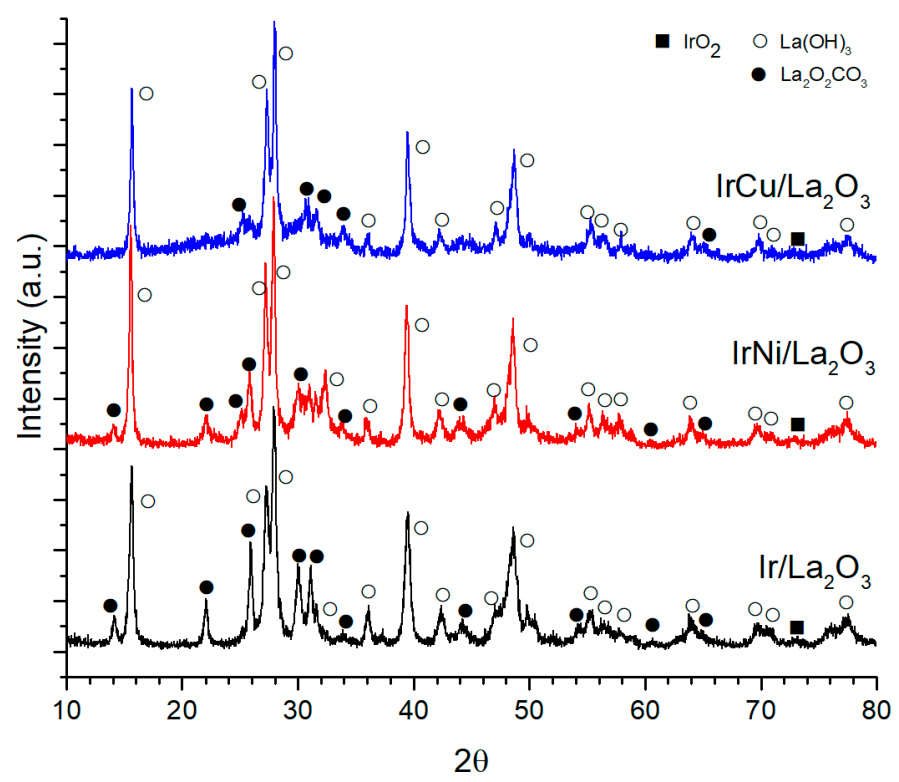

Figure 4. $\mathrm{La}_{2} \mathrm{O}_{3}$ supported catalysts diffraction patterns. 


\subsubsection{Energy Dispersive Spectroscopy}

Figure 5 shows the micrographs of both $\mathrm{CeO}_{2}$ - and $\mathrm{La}_{2} \mathrm{O}_{3}$-supported Iridium catalysts. The images show an adequate dispersion of Ir on both supports. Metal presence in synthesized catalysts was confirmed by EDS and presented in Table 2 .

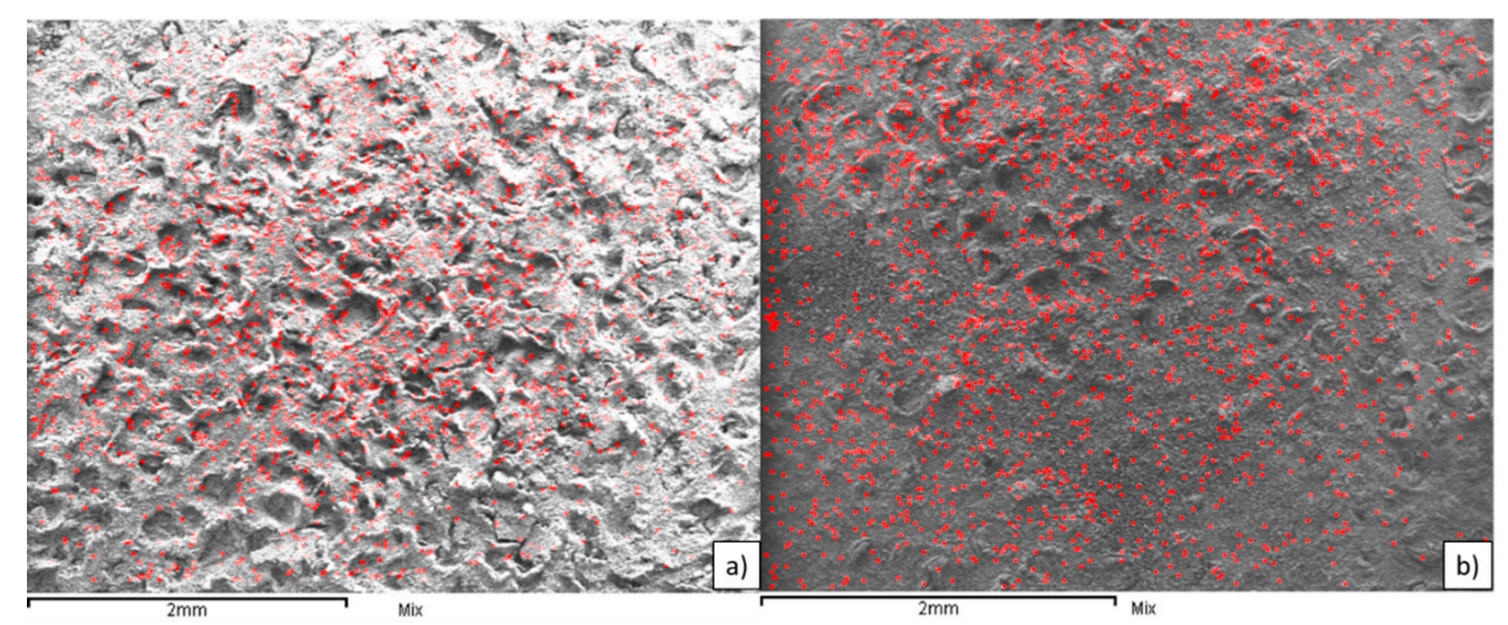

Figure 5. EDS Mapping of (a) $\mathrm{Ir} / \mathrm{CeO}_{2}$; and (b) $\mathrm{Ir} / \mathrm{La}_{2} \mathrm{O}_{3}$.

Table 2. Metal concentration on catalysts (wt \%).

\begin{tabular}{cccc}
\hline Catalyst & Ir & $\mathbf{N i}$ & $\mathbf{C u}$ \\
\hline $\mathrm{Ir} / \mathrm{La}_{2} \mathrm{O}_{3}$ & 3.3 & - & - \\
$\mathrm{IrNi} / \mathrm{La}_{2} \mathrm{O}_{3}$ & 2.8 & 2.2 & - \\
$\mathrm{IrCu} / \mathrm{La}_{2} \mathrm{O}_{3}$ & 2.8 & - & 2.5 \\
$\mathrm{Ir} / \mathrm{CeO}_{2}$ & 3.4 & - & - \\
$\mathrm{IrNi} / \mathrm{CeO}_{2}$ & 3.4 & 2 & - \\
$\mathrm{IrCu} / \mathrm{CeO}_{2}$ & 2.4 & - & 2.7 \\
\hline
\end{tabular}

\subsubsection{X-ray Photoelectron Spectroscopy}

Deposition of Ir on the supports was confirmed through XPS analysis. In Figure 6, XPS results for Ir $4 \mathrm{f}$ components of all catalysts are shown. Ir has previously been found to be in oxidation state +4 , with a doublet of the components $4 \mathrm{f} 7 / 2$ with binding energy between 61.1 and $62 \mathrm{eV}$; and $4 \mathrm{f} 5 / 2$ with binding energy between 64.9 and $65.9 \mathrm{eV}$, with a difference between components of $2.9 \mathrm{eV}$ [37]. XPS spectra for $\mathrm{Cu} 2 \mathrm{p}$ in $\mathrm{La}_{2} \mathrm{O}_{3}$ show low intensity, but the peak corresponding to component 3/2 at $\sim 933 \mathrm{eV}$ can be seen, which is equivalent to $\mathrm{Cu}^{1+}$ oxidation state. $\mathrm{For} \mathrm{CeO}_{2}$, a peak was found at $932.2 \mathrm{eV}$, confirming the presence of $\mathrm{Cu}_{2} \mathrm{O}$. These results can be seen in Figure 7. On the other hand, for $\mathrm{La}_{2} \mathrm{O}_{3}$ no peak could be found that was related to Ni due to overlapping with other peaks; $2 \mathrm{p} 3 / 2$ binding energy values for $\mathrm{Ni}$ species are between 852 and $856 \mathrm{eV}$ [38], and La 3d 3/2 component values are located between 850 and $860 \mathrm{eV}$ [39]. Ni 2s is located around 1000-1010 eV for $\mathrm{NiO}$ [40,41] but it could not be found. For $\mathrm{CeO}_{2}, \mathrm{Ni} 2 \mathrm{p} 3 / 2$ peak was found at $854.54 \mathrm{eV}$ (Figure 8) corresponding to $\mathrm{NiO}$. 

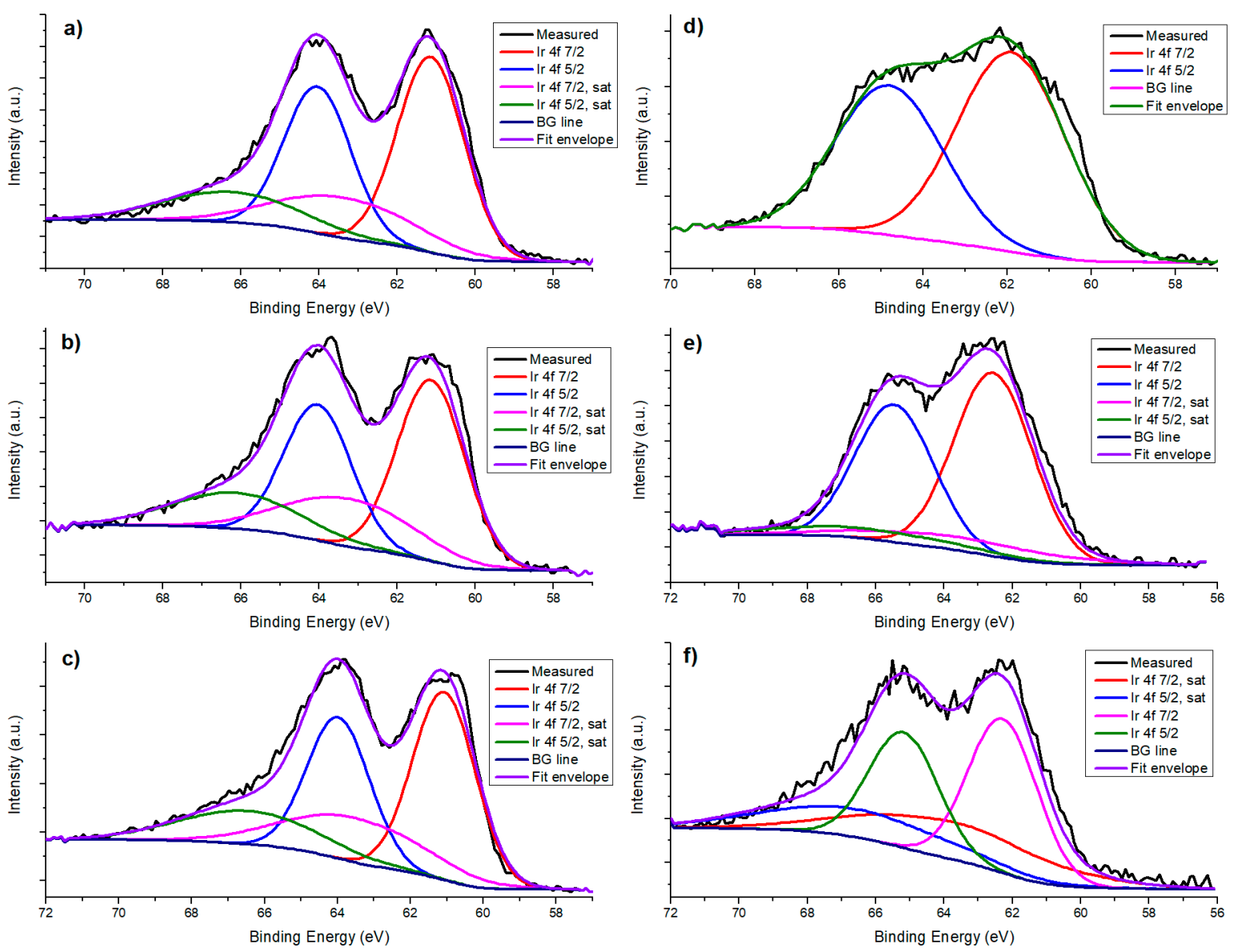

Figure 6. Ir 4f components for catalysts: (a) $\mathrm{Ir} / \mathrm{CeO}_{2} ;$ (b) $\mathrm{IrCu} / \mathrm{CeO}_{2}$; (c) $\mathrm{IrNi} / \mathrm{CeO}_{2}$; (d) $\mathrm{Ir} / \mathrm{La}_{2} \mathrm{O}_{3}$; (e) $\mathrm{IrCu} / \mathrm{La}_{2} \mathrm{O}_{3} ;$ (f) $\mathrm{IrNi} / \mathrm{La}_{2} \mathrm{O}_{3}$.
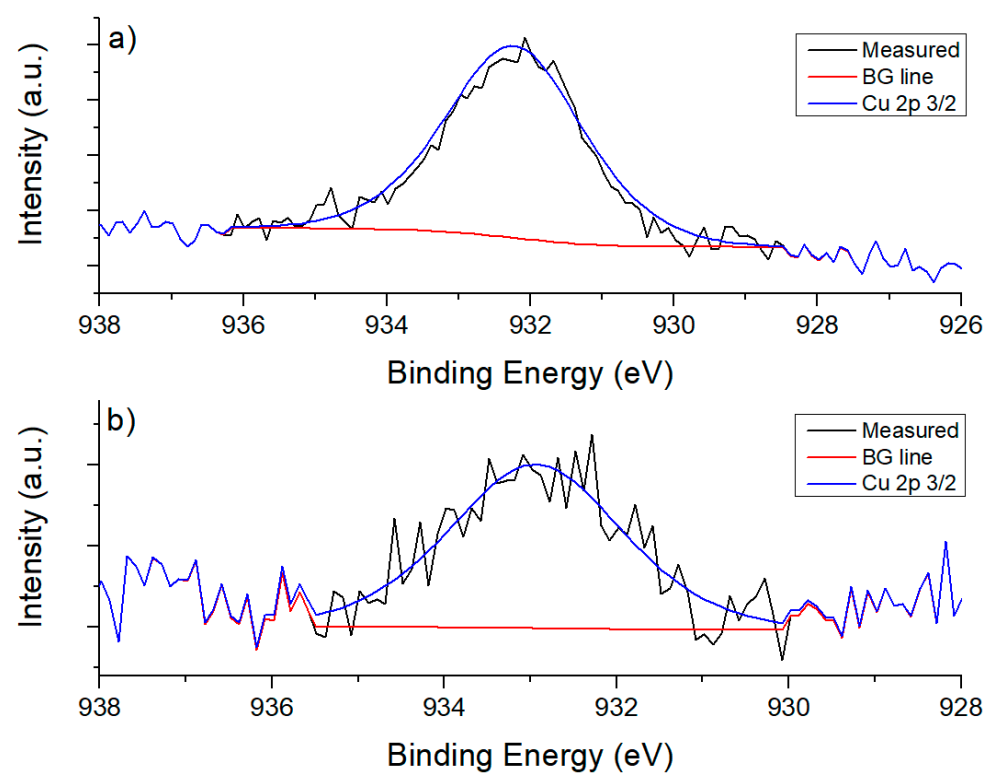

Figure 7. $\mathrm{Cu} 2 \mathrm{p} 3 / 2$ components for catalysts: (a) $\mathrm{IrCu} / \mathrm{CeO}_{2} ;(\mathbf{b}) \mathrm{IrCu} / \mathrm{La}_{2} \mathrm{O}_{3}$. 


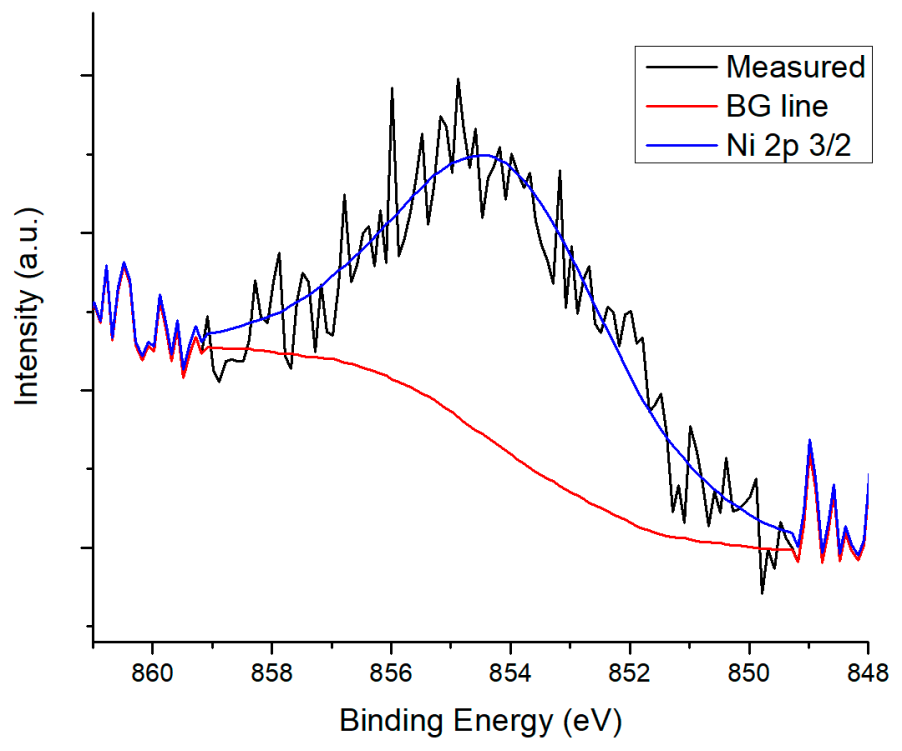

Figure 8. Ni 2 p $3 / 2$ component for $\mathrm{IrNi} / \mathrm{CeO}_{2}$.

\subsection{5. $\mathrm{H}_{2}$ Temperature Programmed Reduction}

Figure 9 shows the TPR profile for $\mathrm{CeO}_{2}$-supported catalysts. For monometallic Ir catalyst, the peak at around $187^{\circ} \mathrm{C}$ corresponds to $\mathrm{IrO}_{2}$ in the bulk of the support, and also shows a shoulder between 100 and $140{ }^{\circ} \mathrm{C}$, corresponding to $\mathrm{IrO}_{2}$ species at the surface. Typically, $\mathrm{CeO}_{2} \mathrm{TPR}$ profile shows two peaks at around $500{ }^{\circ} \mathrm{C}$ and $800{ }^{\circ} \mathrm{C}$ related to reduction at the surface and bulk, respectively [42]. Addition of noble metals promotes the reduction of oxygen species at the surface of $\mathrm{CeO}_{2}$ at temperatures where the noble metal oxide reduces due to the spillover effect $[43,44]$. This phenomenon results in a reduction of Ce(IV) in the bulk, and it can be observed in the broad peak starting at $600{ }^{\circ} \mathrm{C}$. For $\mathrm{IrNi} / \mathrm{CeO}_{2}$, besides the peak and shoulder between 100 and $200{ }^{\circ} \mathrm{C}$ corresponding to the reduction of $\mathrm{IrO}_{2}$, a second peak can also be seen between 200 and $300{ }^{\circ} \mathrm{C}$ that belongs to $\mathrm{NiO}$ species reduction at the surface and the bulk [45]. In the case of $\mathrm{IrCu} / \mathrm{CeO}_{2}$, the first peak at $130{ }^{\circ} \mathrm{C}$ corresponds to $\mathrm{CuO}$ dispersed at the support surface, whereas the second peak is a contribution of $\mathrm{IrO}_{2}$ and $\mathrm{CuO}$ at the bulk, showing a broad shoulder from $200{ }^{\circ} \mathrm{C}$ to $400{ }^{\circ} \mathrm{C}$ [45].

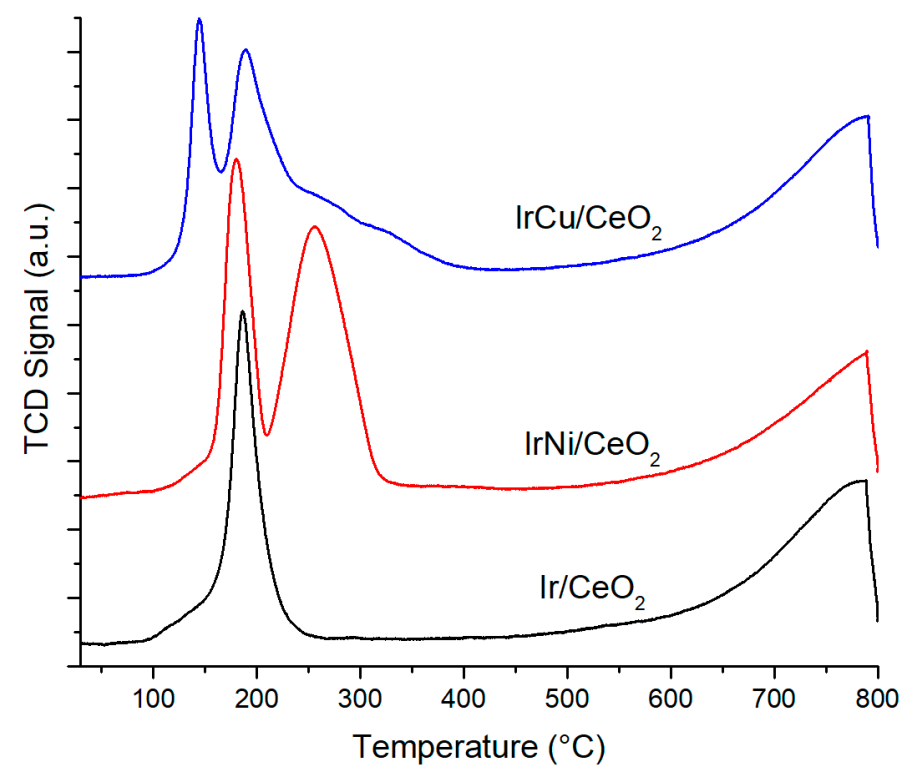

Figure 9. $\mathrm{CeO}_{2}$-supported catalysts TPR profile. 
TPR profiles corresponding to $\mathrm{La}_{2} \mathrm{O}_{3}$-supported catalysts are shown in Figure 10. When compared to $\mathrm{CeO}_{2}$ catalysts, the interaction between $\mathrm{Ir}$ and $\mathrm{La}_{2} \mathrm{O}_{3}$ is more complex. The presence of multiple peaks in the range of $80^{\circ} \mathrm{C}$ and $280{ }^{\circ} \mathrm{C}$ is visible, and they correspond to the reduction of exposed and bulk $\mathrm{IrO}_{2}$ species. There is also a broad peak from $460{ }^{\circ} \mathrm{C}$ to $650{ }^{\circ} \mathrm{C}$ corresponding to $\mathrm{La}(\mathrm{OH})_{3}$ decomposition [46]. For $\mathrm{IrNi} / \mathrm{La}_{2} \mathrm{O}_{3}$, it can be seen that $\mathrm{IrO}_{2}$ species reduction peaks are more defined; the first peak belongs to the reduction of $\mathrm{IrO}_{2}$ at the surface, and peaks between $200{ }^{\circ} \mathrm{C}$ and $300{ }^{\circ} \mathrm{C}$ are a contribution of $\mathrm{IrO}_{2}$ reduction in the bulk and reduction of $\mathrm{NiO}$ species. The slight shift of reduction temperatures for iridium to higher temperatures, and the shift to lower reduction temperatures for $\mathrm{Ni}$ suggest a direct metal-metal interaction because $\mathrm{NiO}$ is normally reduced between 350 and $400{ }^{\circ} \mathrm{C}[47,48]$. Peaks found in the range of 400 to $550{ }^{\circ} \mathrm{C}$ are attributed to a stronger interaction of $\mathrm{NiO}$, and also to the formation of a perovskite-like structure $\mathrm{LaNiO}_{3}$ and $\mathrm{La}_{2} \mathrm{NiO}_{4}$ [49]. For $\mathrm{IrCu} / \mathrm{La}_{2} \mathrm{O}_{3}$, peaks below $400{ }^{\circ} \mathrm{C}$ are contributions of the reduction of both metal oxides. The first peak in the range of 100 to $200{ }^{\circ} \mathrm{C}$ belongs to the reduction of Ir and $\mathrm{Cu}$ dispersed at the surface of support, whereas peaks in the range of 200 to $360^{\circ} \mathrm{C}$ correspond to species of high support interaction, such as reduction from $\mathrm{Cu}^{2+}$ to metallic $\mathrm{Cu}$ in the $\mathrm{La}_{2} \mathrm{CuO}_{4}$ phase $[47,50]$.

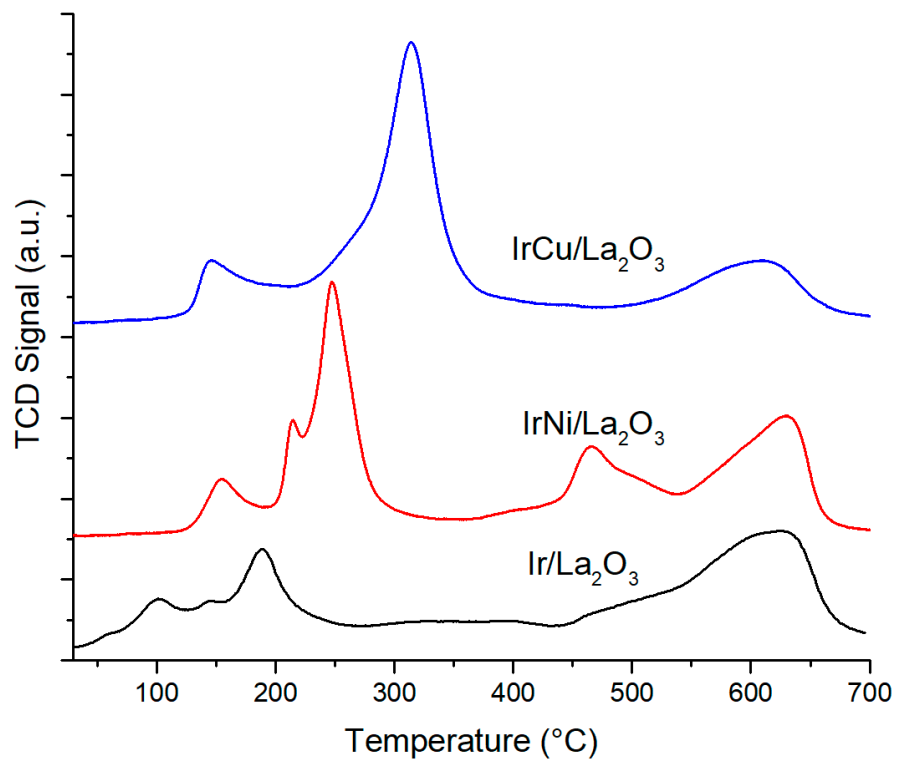

Figure 10. $\mathrm{La}_{2} \mathrm{O}_{3}$-supported catalysts TPR profile.

\subsection{Catalytic Activity}

Figure 11 shows the hydrogen production rate for all catalysts at $270{ }^{\circ} \mathrm{C}$ and 58 bar. Bimetallic IrNi catalysts excel among the others with $150 \mu \mathrm{mol} \mathrm{min}^{-1} \mathrm{~g}_{\mathrm{cat}}{ }^{-1}$ for $\mathrm{CeO}_{2}$ and over $250 \mu \mathrm{mol} \mathrm{min}^{-1} \mathrm{~g}_{\text {cat }}{ }^{-1}$ for $\mathrm{La}_{2} \mathrm{O}_{3}$. These results are due to high activity on the C-C bonds cleavage of Ni. Synthesized $\mathrm{IrNiLa}_{2} \mathrm{O}_{3}$ is competitive with others catalyst using $\mathrm{Pt}$, as reported by Wen et al. [51]. They prepared different $\mathrm{Al}_{2} \mathrm{O}_{3}$-supported catalysts with metals such as $\mathrm{Pt}, \mathrm{Ni}, \mathrm{Co}, \mathrm{Cu}$. Best performance was achieved by $\mathrm{Pt}(4.38 \mathrm{wt} \%)$, with a stable rate of $\mathrm{H}_{2}$ production around $550 \mu \mathrm{mol} \mathrm{min}{ }^{-1} \mathrm{~g}_{\text {cat }}{ }^{-1}$. $\mathrm{Ni}, \mathrm{Co}$, and $\mathrm{Cu}$ showed catalyst deactivation and a decrease of $\mathrm{H}_{2}$ production over time. $\mathrm{Ni} / \mathrm{Al}_{2} \mathrm{O}_{3}$ achieved around $250 \mathrm{mmol}$ in the first hour, but after $200 \mathrm{~min}$, it decreased below 100. Deactivation for $\mathrm{Al}_{2} \mathrm{O}_{3}$ was related to carbon deposition during reaction. Besides, $\mathrm{C}$ to gas conversion was $18.9 \%, 15.8 \%$ and $2 \%$ for $\mathrm{Pt}, \mathrm{Ni}$ and $\mathrm{Cu}$ catalysts, respectively. Other Pt catalysts reported were $\mathrm{Pt}(4.34 \mathrm{wt} \%) / \mathrm{SiO}_{2}, \mathrm{Pt}(4.23 \mathrm{wt} \%) / \mathrm{AC}, \mathrm{Pt}(9.84 \mathrm{wt} \%) / \mathrm{MgO}, \mathrm{Pt}(5.1 \mathrm{wt} \%) / \mathrm{HUSY}$, $\mathrm{Pt}(5.31 \mathrm{wt} \%)$ /MSAPO-11 with 369.4, 307.7, 431.9, 337, and $221.1 \mu \mathrm{mol} \mathrm{min}^{-1} \mathrm{~g}_{\text {cat }}{ }^{-1}$, respectively.

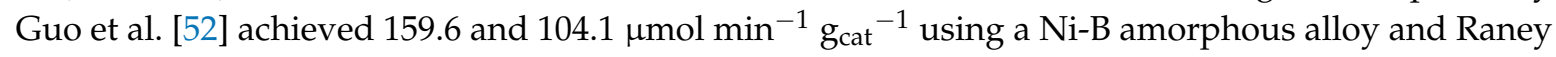
Ni catalysts, respectively, with $\mathrm{C}$ to gas conversion below $12 \%$ for both catalysts. 


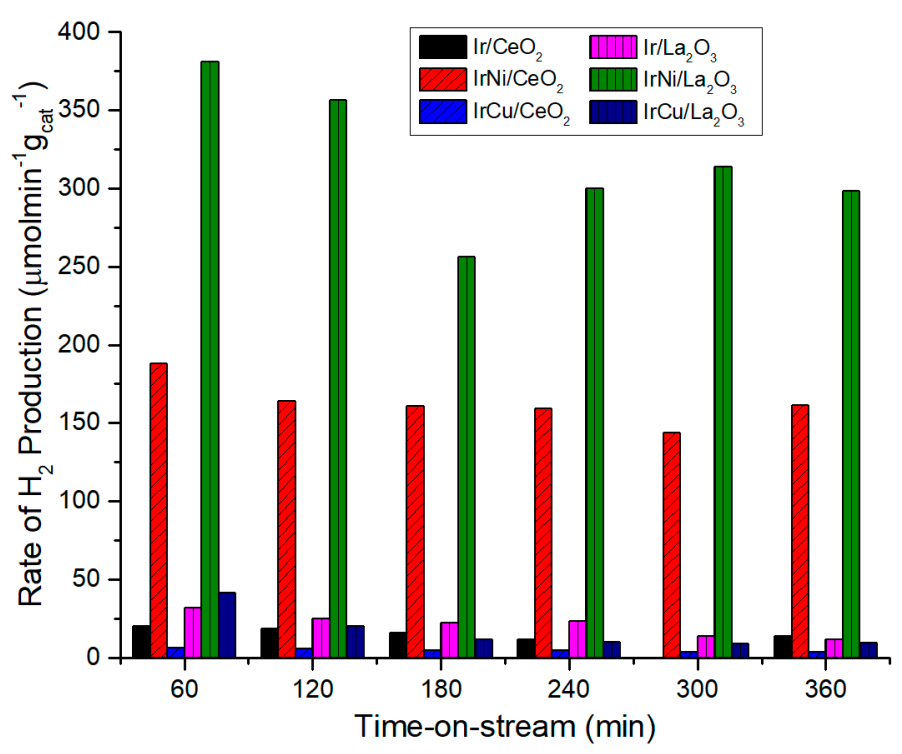

Figure 11. $\mathrm{H}_{2}$ Yield Rate at $270{ }^{\circ} \mathrm{C}$ and 58 bar.

The support also plays an essential role in hydrogen production. Almost every $\mathrm{La}_{2} \mathrm{O}_{3}$ supported catalyst achieved a higher $\mathrm{H}_{2}$ production yield than $\mathrm{CeO}_{2}$-supported catalysts, due to a higher pore volume and a better metal-support interaction. As discussed before, $\mathrm{La}_{2} \mathrm{O}_{3}$ is highly hygroscopic and interacts with moisture and the air of the environment during its manipulation, forming other phases $\left(\mathrm{La}(\mathrm{OH})_{3}\right.$ and $\left.\mathrm{La}_{2} \mathrm{O}_{3} \mathrm{CO}_{3}\right)$. Furthermore, aqueous-phase reforming is carried out in the presence of water, and $\mathrm{CO}_{2}$ is also formed during reaction. $\mathrm{La}_{2} \mathrm{O}_{2} \mathrm{CO}_{3}$ phase in $\mathrm{La}_{2} \mathrm{O}_{3}$ catalysts interacts with carbon deposits on the catalysts surface, giving place to $\mathrm{CO}$ formation. This compound is harnessed in the water-gas shift reaction, forming more $\mathrm{H}_{2}$. This effect results in a higher hydrogen production. On the other hand, a higher resistance to deactivation was observed for the $\mathrm{IrNi} / \mathrm{La}_{2} \mathrm{O}_{3}$ catalyst. This can be attributed to the removal of carbon formed on $\mathrm{Ni}$ sites by oxygen species from the carbonate as mentioned above [36,53]. It can also be seen that monometallic Ir catalysts exhibited a better $\mathrm{H}_{2}$ production than bimetallic $\mathrm{IrCu}$ catalysts, although it was expected to have a synergetic performance due to $\mathrm{Cu}$ activity in water-gas shift reaction. This may be caused by a $\mathrm{Cu}$ sintering while reducing the catalyst, thus covering Ir particles and lowering the metal-substrate contact area.

Figure 12 shows the catalyst selectivity towards $\mathrm{H}_{2}$ at $270{ }^{\circ} \mathrm{C}$ and 58 bar. For $\mathrm{La}_{2} \mathrm{O}_{3}$ catalysts, $\mathrm{IrNi} / \mathrm{La}_{2} \mathrm{O}_{3}$ shows a stable $\mathrm{H}_{2}$ selectivity even in the small decrease in its activity during the reaction tests, while $\mathrm{Ir} / \mathrm{La}_{2} \mathrm{O}_{3}$ and $\mathrm{IrCu} / \mathrm{La}_{2} \mathrm{O}_{3}$ exhibit a significant decrease from over $100 \%$ to $30-50 \%$, related to a higher catalyst deactivation. $\mathrm{H}_{2}$ selectivity values are higher than $100 \%$ because they are compared against gaseous $\mathrm{C}$ products as stated in Equation (2). $\mathrm{For} \mathrm{CeO}_{2}$ support, all catalysts showed a low but stable selectivity along the reaction at around $20-45 \%$. Carbon to gas conversion at $270{ }^{\circ} \mathrm{C}$ and 58 bar is presented in Figure 13. Once again, bimetallic Ni catalysts had the highest value among all catalysts. The low $C$ to gas conversion of the rest of the catalysts indicates that they are not active enough to break the glycerol molecule and its liquid byproducts to produce hydrogen. Liquid products of reactions include compounds such as acetaldehyde, acetone, acetic acid, methyl alcohol, ethanol, 1-hydroxy-2-Propanone, R-(-)-1,2-propanediol, 1,2-Ethanediol, and propylene glycol.

Figures 14 and 15 show $\mathrm{CH}_{4}$ and $\mathrm{CO}$ selectivity of catalysts, respectively. Bimetallic Ni catalysts showed less $\mathrm{CH}_{4}$ selectivity than monometallic Ir catalysts, resulting in higher $\mathrm{CO}$ selectivity. It may suggest that even though Ir is less active in the methanation reaction, when $\mathrm{Ni}$ is added, a synergetic effect occurs and methanation reduces. This result is of particular interest because not only $\mathrm{Ni}$ increases $\mathrm{H}_{2}$ production of $\mathrm{Ir}$ catalysts, it also decreases the formation of $\mathrm{CH}_{4}$. This phenomenon can be attributed to the increase of metal-support interaction after the addition of $\mathrm{Ni}$ to Ir catalysts due to a better active species dispersion [54]. 


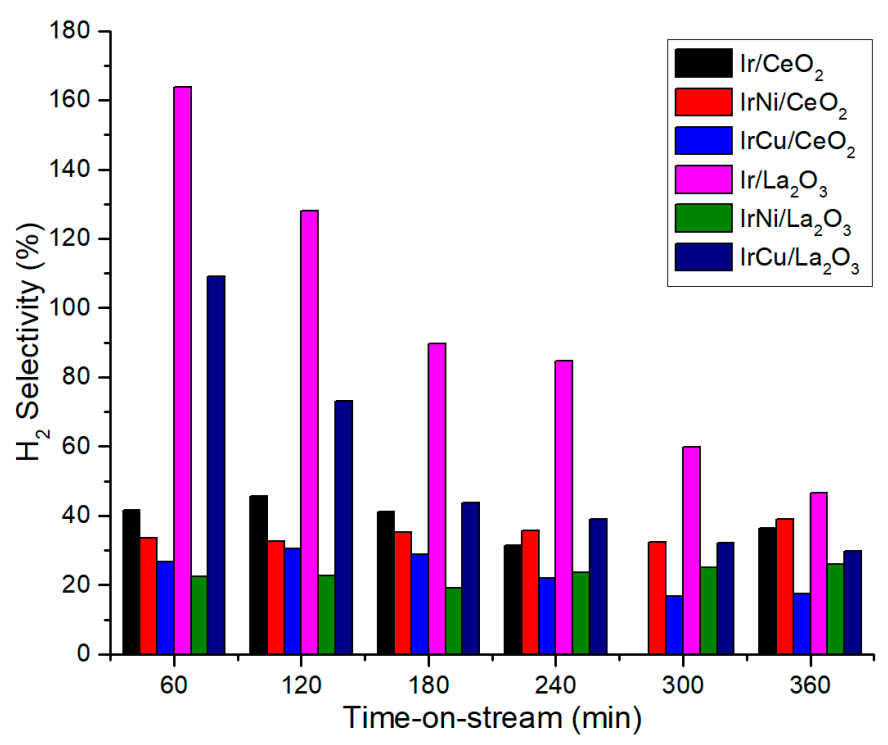

Figure 12. $\mathrm{H}_{2}$ Selectivity at $270{ }^{\circ} \mathrm{C}$ and 58 bar.

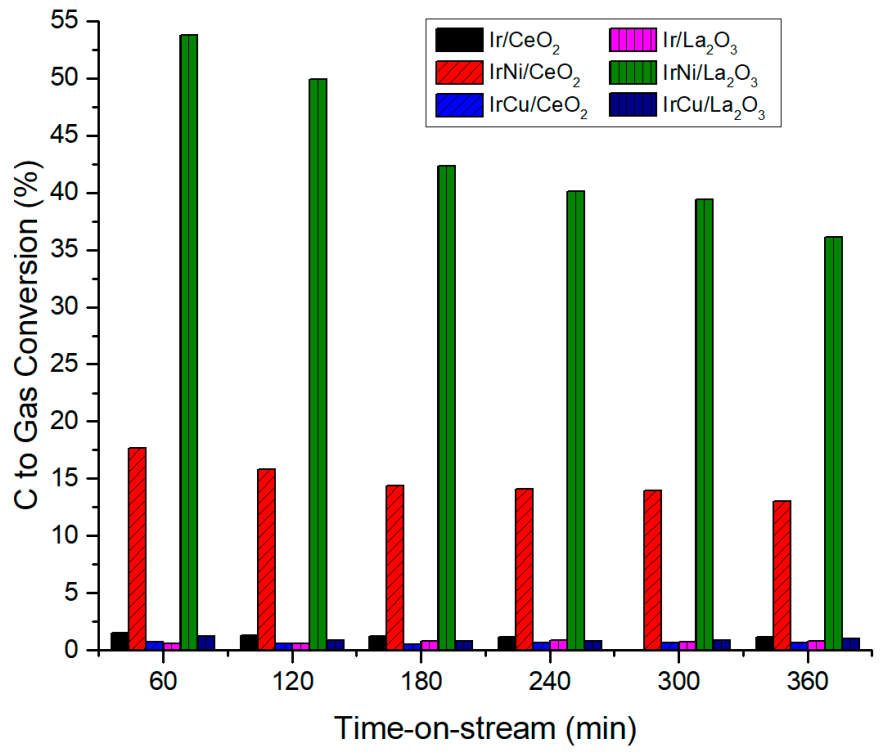

Figure 13. $\mathrm{C}$ to gas conversion at $270{ }^{\circ} \mathrm{C}$ and 58 bar.

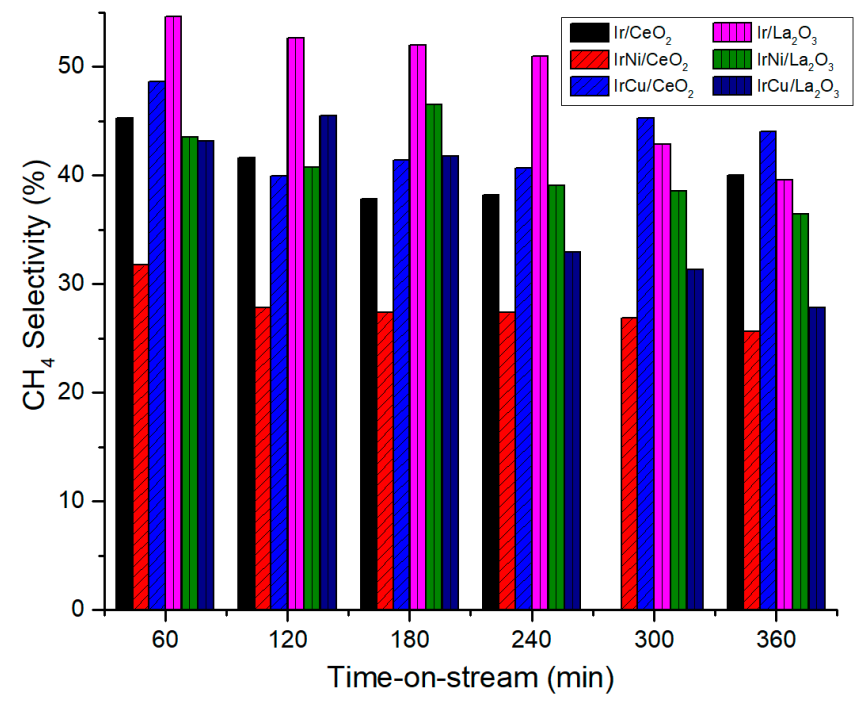

Figure 14. $\mathrm{CH}_{4}$ Selectivity at $270{ }^{\circ} \mathrm{C}$ and 58 bar. 


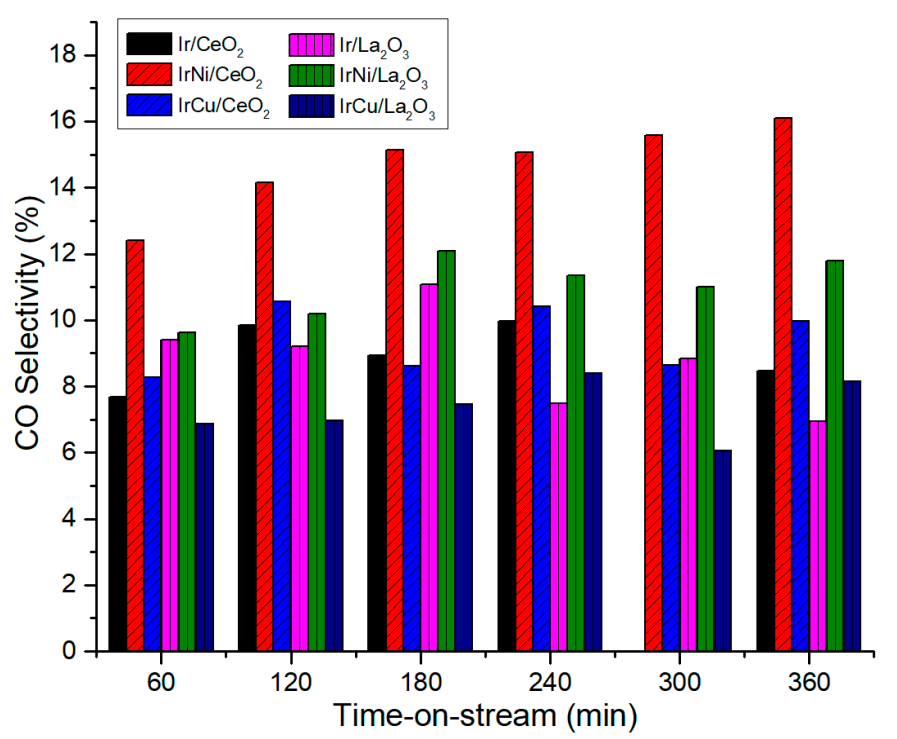

Figure 15. CO Selectivity at $270{ }^{\circ} \mathrm{C}$ and 58 bar.

Table 3 summarizes average glycerol conversion, $\mathrm{C}$ to gas conversion, yield rate of $\mathrm{H}_{2}$ production and selectivities (to $\mathrm{H}_{2}, \mathrm{CH}_{4}, \mathrm{CO}, \mathrm{CO}_{2}$ ) for all catalysts. The best catalyst was $\mathrm{IrNi} / \mathrm{La}_{2} \mathrm{O}_{3}$. Although this catalyst has the lowest $\mathrm{H}_{2}$ selectivity, it is remarkable regarding glycerol and $\mathrm{C}$ to gas conversion. For instance, Manfro et al. [55] prepared $\mathrm{Ni} / \mathrm{CeO}_{2}$ catalysts by different methods. NiCe-Com (prepared by combustion) achieved $30 \%$ glycerol conversion after $12 \mathrm{~h}$ of reaction ( $1 \mathrm{wt} \%$ glycerol, $543 \mathrm{~K})$, against $24 \%$ for NiCe-Imp. (prepared by impregnation).

Table 3. APR performance of catalysts at $270^{\circ} \mathrm{C}$ and 58 bar. Average of six hours of reaction.

\begin{tabular}{|c|c|c|c|c|c|c|c|}
\hline Catalyst & 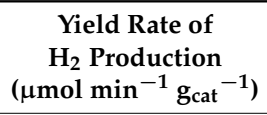 & $\begin{array}{c}\text { Glycerol } \\
\text { Conversion }(\%)\end{array}$ & $\mathrm{S}-\mathrm{H}_{2}(\%)$ & $\mathrm{S}-\mathrm{CH}_{4}(\%)$ & S-CO (\%) & $\mathrm{S}-\mathrm{CO}_{2}(\%)$ & $\begin{array}{l}\text { C to GAS } \\
\text { Conv. }(\%)\end{array}$ \\
\hline $\mathrm{Ir} / \mathrm{La}_{2} \mathrm{O}_{3}$ & 21.2 & 58.2 & 95.4 & 48.8 & 8.8 & 42.4 & 0.7 \\
\hline $\mathrm{IrCu} / \mathrm{La}_{2} \mathrm{O}_{3}$ & 16.9 & 76.5 & 54.5 & 37.1 & 7.3 & 55.6 & 0.9 \\
\hline $\mathrm{IrNi} / \mathrm{La}_{2} \mathrm{O}_{3}$ & 317.7 & 92.0 & 23.1 & 40.8 & 11.0 & 48.2 & 43.6 \\
\hline $\mathrm{Ir} / \mathrm{CeO}_{2}$ & 16.0 & 52.6 & 39.3 & 40.6 & 9.0 & 50.4 & 1.3 \\
\hline $\mathrm{IrCu} / \mathrm{CeO}_{2}$ & 4.7 & 35.5 & 23.7 & 43.3 & 9.4 & 473. & 0.6 \\
\hline $\mathrm{IrNi} / \mathrm{CeO}_{2}$ & 162.9 & 55.7 & 34.8 & 27.8 & 14.7 & 57.5 & 14.8 \\
\hline
\end{tabular}

\section{Materials and Methods}

\subsection{Preparation of Catalysts}

Iridium, iridium-nickel, and iridium-copper ( $\mathrm{Ir}, \mathrm{IrNi}$, and $\mathrm{IrCu}$ from now on) catalysts were prepared by incipient wetness impregnation using two supports: $\mathrm{CeO}_{2}(99.9 \%$ trace metals basis) and $\mathrm{La}_{2} \mathrm{O}_{3}(\geq 99.9 \%)$. All materials were purchased from Sigma-Aldrich.

For the preparation of monometallic iridium catalyst, the amount of $\mathrm{IrCl}_{3} \cdot \mathrm{H}_{2} \mathrm{O}$ (reagent grade) corresponding to Ir $3 \mathrm{wt} \%$ of the catalyst was added to ethanol and stirred until it was dissolved. The solution was added dropwise to the support, heated at $110^{\circ} \mathrm{C}$ overnight and calcined in flowing oxygen at $550{ }^{\circ} \mathrm{C}$ for $4 \mathrm{~h}$. Bimetallic $\operatorname{IrNi}(\operatorname{Ir} 3 \mathrm{wt} \%, \mathrm{Ni} 3 \mathrm{wt} \%)$ and $\operatorname{IrCu}(\operatorname{Ir} 3 \mathrm{wt} \%, \mathrm{Cu} 3 \mathrm{wt} \%)$ catalysts were synthesized using a mixture of $\mathrm{IrCl}_{3} \cdot \mathrm{H}_{2} \mathrm{O}$ and $\mathrm{Ni}\left(\mathrm{NO}_{3}\right)_{2} \cdot 6 \mathrm{H}_{2} \mathrm{O}$ (purum p.a.) or $\mathrm{Cu}\left(\mathrm{NO}_{3}\right)_{2} \cdot 3 \mathrm{H}_{2} \mathrm{O}$ (puriss, p.a.), dissolved in ethanol. The solutions were added dropwise to the support and calcined following the same procedure.

\subsection{Catalysts Characterization}

X-ray diffraction (XRD) patterns were recorded using a Bruker D8-Advance diffractometer with a $\mathrm{CuK} \alpha$ radiation source operated at $40 \mathrm{kV}$ and $30 \mathrm{~mA}$ (Billerica, MA, USA). X-ray photoelectron 
spectroscopy (XPS) analysis was performed with a K-Alpha Thermo Scientific spectrometer (Waltham, MA, USA) using an AlK $\alpha$ X-ray monochromatic source of $1486.6 \mathrm{eV}$ at $12 \mathrm{kV}$ and 40 Watts. A copper adhesive tape was placed on a stainless-steel holder to fix the powder samples. The analyzed area was of $400 \mu \mathrm{m}$ using an incident relative angle of $30^{\circ}$. Before analysis, the surfaces the of samples were cleaned upon argon erosion for $30 \mathrm{~s}$ at $3 \mathrm{kV}$ and $30 \mathrm{~W}$. Survey spectra were obtained from 0 to $1350 \mathrm{eV}$ using $1 \mathrm{eV} /$ step and $100 \mathrm{eV}$ pass energy, whereas $0.1 \mathrm{eV} /$ step and $50 \mathrm{eV}$ pass energy were used for high-resolution spectra. The binding energies $( \pm 0.2 \mathrm{eV})$ were referenced to $\mathrm{C} 1 \mathrm{~s}$ of adventitious carbon at $284.8 \mathrm{eV}$. Textural properties of catalysts were measured by $\mathrm{N}_{2}$ physisorption at $77 \mathrm{~K}$ using a Quantachrome Instrument NOVA 2200e equipment (Boynton Beach, FL, USA). Before the measurement, the samples were degassed at $573 \mathrm{~K}$ for $16 \mathrm{~h}$ under vacuum. The specific surface area was determined from the BET plot. The pore volume was calculated from the desorption branch of $\mathrm{N}_{2}$ physisorption isotherm. Energy-dispersive X-ray spectroscopy (EDX) analyses were performed with a JEOL JSM-6360LV (Peabody, MA, USA) High-Resolution Scanning Electron Microscope coupled to an Electron Dispersion Scanning X-Ray (EDX). TPR profiles were obtained using a Micromeritics AutoChem II 2920 Automated Catalyst Characterization System (Norcross, GA, USA) with a Thermal Conductivity Detector. The particle size of catalysts was reduced to $40-60$ mesh. Then, $100 \mathrm{mg}$ were packed between glass wool in a quartz U-tube used as a reduction cell. The tube was then placed inside an oven connected to a CryoCooler system. Before analysis, $100 \mathrm{mg}$ of fresh catalyst was pretreated in a $20 \% \mathrm{O}_{2}-\mathrm{N}_{2}$ gas mixture at $300{ }^{\circ} \mathrm{C}$ for $60 \mathrm{~min}$. Then, the temperature was reduced in the presence of argon $\left(30 \mathrm{~cm}^{3} / \mathrm{min}\right)$. TPR profile was then measured from 30 to $800{ }^{\circ} \mathrm{C}$ at $10{ }^{\circ} \mathrm{C} /$ min under $5 \%$ $\mathrm{H}_{2} /$ He flow.

\subsection{Activity Test}

The evaluation of the catalytic behavior during the glycerol APR was performed in a down-flow fixed-bed reactor (Microactivity Reference, $0.9 \mathrm{~cm}$ diameter) operated at $543 \mathrm{~K}$ and 58 bar. Before the reaction, $612 \mathrm{mg}$ of each catalyst were reduced at $550{ }^{\circ} \mathrm{C}$ under a hydrogen stream $(50 \mathrm{~mL} / \mathrm{min}, 1.5 \mathrm{~h}$, heating ramp $5{ }^{\circ} \mathrm{C} / \mathrm{min}$ ) and then heated up to the reaction temperature in a nitrogen atmosphere at the desired pressure. A $10 \mathrm{wt} \%$ aqueous glycerol solution (glycerol $\geq 99.5 \%$ ) was fed at $0.25 \mathrm{~mL} / \mathrm{min}$ with a WHSV of $2.5 \mathrm{~h}^{-1}$ and a time-on-stream of $6 \mathrm{~h}$. Reaction products were separated in a condensation cell. Gas products were stored in 0.61 sampling bags (every hour, at reaction time $=30 \mathrm{~min}$, a sampling bag was connected to the gas exit for $10 \mathrm{~min}$, then it was changed for another sampling bag. In total, three sampling bags were used every hour of reaction), then they were analyzed in a Portable Syngas Analyzer ETG MCA 100 SYN-P (Montiglio, AT, Italy). According to the calibration of measuring equipment, errors in estimation are less than $1.2 \%$; Liquid products were stored in $20 \mathrm{~mL}$ amber bottles and then analyzed by a Gas Chromatograph Young Lin GC-6500 (Anyang-si, Gyeonggi-do, Korea) using a Mass-selective Detector equipped with a MEGA-Wax column (internal diameter $=0.32 \mathrm{~mm}$, length $=25 \mathrm{~m}$ ). The method employed started at $31^{\circ} \mathrm{C}$ for $3 \mathrm{~min}$, and then it was heated to $200{ }^{\circ} \mathrm{C}$ at $15^{\circ} \mathrm{C} / \mathrm{min}$.

Acquired data were processed according to the following definitions [56]:

$$
\begin{gathered}
\text { Conversion }=\left(\frac{\text { glycerol moles } \text { fed }- \text { glycerol moles in products }}{\text { glycerol moles fed }}\right) \times 100 \%, \\
S_{H_{2}}=\left(\frac{H_{2} \text { molecules produced }}{\text { C atoms in gas product }}\right) \times\left(\frac{1}{R}\right) \times 100 \%,
\end{gathered}
$$

where $R$ is the $\mathrm{H}_{2} / \mathrm{CO}_{2}$ reforming ratio of glycerol (7/3);

$$
S_{i}=\left(\frac{\text { moles of } i \text { species produced experimentally }}{C \text { moles in gas products }}\right) \times 100 \%,
$$


where $i$ is for $\mathrm{CH}_{4}, \mathrm{CO}$ or $\mathrm{CO}_{2}$, and

$$
\text { C conversion to gas }=\left(\frac{\text { C in gas products }}{C \text { fed into reactor }}\right) \times 100 \% \text {. }
$$

\section{Conclusions}

Experimental investigation of Ir and Ir-bimetallic catalysts performance for $\mathrm{H}_{2}$ production using glycerol as a substrate under aqueous phase reforming conditions was performed for the first time.

Ir-based catalysts were synthesized using $\mathrm{La}_{2} \mathrm{O}_{3}$ and $\mathrm{CeO}_{2}$ supports. Although $\mathrm{H}_{2}$ selectivity was low, $\mathrm{IrNi} / \mathrm{CeO}_{2}$ and $\mathrm{IrNi} / \mathrm{La}_{2} \mathrm{O}_{3}$ catalyst showed potential for hydrogen production. $\mathrm{IrNi} / \mathrm{La}_{2} \mathrm{O}_{3}$ catalyst showed the highest glycerol conversion $(92.02 \%)$ and rate of hydrogen production $\left(317.65 \mu \mathrm{mol} \mathrm{min}{ }^{-1} \mathrm{gcat}^{-1}\right)$. Ir by itself was apparently not capable of breaking glycerol's C-C bonds. Besides, despite the relative high glycerol conversion ( $\sim 52$ and $58 \%$ for $\mathrm{CeO}_{2}$ and $\mathrm{La}_{2} \mathrm{O}_{3}$, respectively), there was low $\mathrm{C}$ to gas conversion (below $2 \%$ for both supports) meaning that low $\mathrm{CH}_{4}, \mathrm{CO}_{2}$ and $\mathrm{CO}$ is being produced. $\mathrm{CO}$ is important because it is part of the water-gas shift reaction and this step is fundamental for hydrogen production. The expected synergetic effect between the activities of Ir and $\mathrm{Cu}$ was not achieved due to possible sintering of the latter. Nevertheless, a reduction in $\mathrm{CH}_{4}$ selectivity was observed while adding $\mathrm{Ni}$ to Ir regarding of the support. Ir ( $3 \mathrm{wt} \%$ ) did not show relevance to $\mathrm{H}_{2}$ production by itself, but when combined with other metals, or with a higher metal charge, it could be a promising material.

Author Contributions: F.E. conceived, designed, and performed the experiments; investigation, F.E, P.B, M.R.-G., S.T.-B.; Funding acquisition and research leader, J.C.C.-H.; resources, J.C.C.-H., W.S.; all authors discussed the results and commented on the manuscript.

Funding: This research and the APC were funded by CONACYT-SENER/SUSTENTABILIDAD ENERGÉTICA, grant number FSE-2014-01-254667.

Acknowledgments: Juan C. Chavarria acknowledges the financial support of the FSE-2014-01-254667 project. Francisco Espinosa acknowledges CONACyT for the scholarship given to fulfill PhD studies. Tanit Toledano, Anel I. Castillo, Cintya M. Gómez, and Santiago Duarte are acknowledged for help with EDS, $\mathrm{N}_{2}$ physisorption, chromatography and gas-analyzer measurements, respectively. To Wilian Cauich (LANNBIO Cinvestav) for XPS measurements.

Conflicts of Interest: The authors declare no conflict of interest.

\section{References}

1. Newell, R.G.; Qian, Y.; Raimi, D. Global Energy Outlook 2015. 2016. Available online: http:/ / www.nber.org/ papers/w22075 (accessed on 29 March 2016).

2. Council, W.E. World Energy Resources 2016. Available online: https:/ /www.worldenergy.org/wp-content/ uploads/2016/10/World-Energy-Resources-Full-report-2016.10.03.pdf (accessed on 25 April 2017).

3. Höök, M.; Tang, X. Depletion of fossil fuels and anthropogenic climate change-A review. Energy Policy 2013, 52, 797-809. [CrossRef]

4. Chiari, L.; Zecca, A. Constraints of fossil fuels depletion on global warming projections. Energy Policy 2011, 39, 5026-5034. [CrossRef]

5. Hoel, M.; Kverndokk, S. Depletion of fossil fuels and the impacts of global warming. Resour. Energy Econ. 1996, 18, 115-136. [CrossRef]

6. Escobar, J.C.; Lora, E.S.; Venturini, O.J.; Yáñez, E.E.; Castillo, E.F.; Almazan, O. Biofuels: Environment, technology and food security. Renew. Sustain. Energy Rev. 2009, 13, 1275-1287. [CrossRef]

7. Nigam, P.S.; Singh, A. Production of liquid biofuels from renewable resources. Prog. Energy Combust. Sci. 2011, 37, 52-68. [CrossRef]

8. Da Silva Veras, T.; Mozer, T.S.; da Silva César, A. Hydrogen: Trends, production and characterization of the main process worldwide. Int. J. Hydrog. Energy 2017, 42, 2018-2033. [CrossRef]

9. Sherif, S.A.; Barbir, F.; Veziroglu, T.N. Towards a Hydrogen Economy. Electr. J. 2005, 18, 62-76. [CrossRef] 
10. Davda, R.R.; Shabaker, J.W.; Huber, G.W.; Cortright, R.D.; Dumesic, J.A. A review of catalytic issues and process conditions for renewable hydrogen and alkanes by aqueous-phase reforming of oxygenated hydrocarbons over supported metal catalysts. Appl. Catal. B Environ. 2005, 56, 171-186. [CrossRef]

11. Mazloomi, K.; Gomes, C. Hydrogen as an energy carrier: Prospects and challenges. Renew. Sustain. Energy Rev. 2012, 16, 3024-3033. [CrossRef]

12. Holladay, J.D.; Hu, J.; King, D.L.; Wang, Y. An overview of hydrogen production technologies. Catal. Today 2009, 139, 244-260. [CrossRef]

13. Cifuentes, B.; Valero, M.; Conesa, J.; Cobo, M. Hydrogen Production by Steam Reforming of Ethanol on Rh-Pt Catalysts: Influence of $\mathrm{CeO}_{2}, \mathrm{ZrO}_{2}$, and $\mathrm{La}_{2} \mathrm{O}_{3}$ as Supports. Catalysts 2015, 5, 1872-1896. [CrossRef]

14. Mhadmhan, S.; Natewong, P.; Prasongthum, N.; Samart, C.; Reubroycharoen, P. Investigation of Ni/SiO 2 Fiber Catalysts Prepared by Different Methods on Hydrogen production from Ethanol Steam Reforming. Catalysts 2018, 8, 319. [CrossRef]

15. Dincer, I.; Acar, C. Review and evaluation of hydrogen production methods for better sustainability. Int. J. Hydrog. Energy 2015, 40, 11094-11111. [CrossRef]

16. Cortright, R.D.; Davda, R.R.; Dumesic, J.A. Hydrogen from catalytic reforming of biomass-derived hydrocarbons in liquid water. Nature 2002, 418, 964-967. [CrossRef] [PubMed]

17. Shabaker, J.W.; Huber, G.W.; Davda, R.R.; Cortright, R.D.; Dumesic, J.A. Aqueous-Phase Reforming of Ethylene Glycol Over Supported Platinum Catalysts. Catal. Lett. 2003, 88, 1-8. [CrossRef]

18. Shabaker, J.W.; Davda, R.R.; Huber, G.W.; Cortright, R.D.; Dumesic, J.A. Aqueous-phase reforming of methanol and ethylene glycol over alumina-supported platinum catalysts. J. Catal. 2003, 215, 344-352. [CrossRef]

19. Joensen, F.; Rostrup-Nielsen, J.R. Conversion of hydrocarbons and alcohols for fuel cells. J. Power Sources 2002, 105, 195-201. [CrossRef]

20. Soares, R.R.; Simonetti, D.A.; Dumesic, J.A. Glycerol as a Source for Fuels and Chemicals by Low-Temperature Catalytic Processing. Angew. Chem. 2006, 45, 3982-3985. [CrossRef]

21. Özgür, D.Ö.; Uysal, B.Z. Hydrogen production by aqueous phase catalytic reforming of glycerine. Biomass Bioenergy 2011, 35, 822-826. [CrossRef]

22. Miyao, T.; Watanabe, Y.; Teramoto, M.; Naito, S. Catalytic activity of various supported Ir-Re catalysts for liquid phase methanol reforming with water. Catal. Commun. 2005, 6, 113-117. [CrossRef]

23. Sakamoto, T.; Miyao, T.; Yoshida, A.; Naito, S. Effect of Re and Mo addition upon liquid phase methanol reforming with water over $\mathrm{SiO}_{2}, \mathrm{ZrO}_{2}$ and $\mathrm{TiO}_{2}$ supported $\mathrm{Ir}$ catalysts. Int. J. Hydrog. Energy 2010, 35, 6203-6209. [CrossRef]

24. Davda, R.R.; Shabaker, J.W.; Huber, G.W.; Cortright, R.D.; Dumesic, J.A. Aqueous-phase reforming of ethylene glycol on silica-supported metal catalysts. Appl. Catal. B Environ. 2003, 43, 13-26. [CrossRef]

25. Nozawa, T.; Yoshida, A.; Hikichi, S.; Naito, S. Effects of Re addition upon aqueous phase reforming of ethanol over $\mathrm{TiO}_{2}$ supported $\mathrm{Rh}$ and Ir catalysts. Int. J. Hydrog. Energy 2015, 40, 4129-4140. [CrossRef]

26. Yang, G.; Yu, H.; Huang, X.; Peng, F.; Wang, H. Effect of calcium dopant on catalysis of $\mathrm{Ir} / \mathrm{La}_{2} \mathrm{O}_{3}$ for hydrogen production by oxidative steam reforming of glycerol. Appl. Catal. B Environ. 2012, 127, 89-98. [CrossRef]

27. Wang, F.; Cai, W.; Tana; Provendier, H.; Schuurman, Y.; Descorme, C.; Mirodatos, C.; Shen, W. Ageing analysis of a model Ir $/ \mathrm{CeO}_{2}$ catalyst in ethanol steam reforming. Appl. Catal. B Environ. 2012, 125, 546-555. [CrossRef]

28. Cai, W.; Zhang, B.; Li, Y.; Xu, Y.; Shen, W. Hydrogen production by oxidative steam reforming of ethanol over an $\mathrm{Ir} / \mathrm{CeO}_{2}$ catalyst. Catal. Commun. 2007, 8, 1588-1594. [CrossRef]

29. Zhang, B.; Cai, W.; Li, Y.; Xu, Y.; Shen, W. Hydrogen production by steam reforming of ethanol over an $\mathrm{Ir} / \mathrm{CeO}_{2}$ catalyst: Reaction mechanism and stability of the catalyst. Int. J. Hydrog. Energy 2008, 33, 4377-4386. [CrossRef]

30. Cai, W.; Wang, F.; Zhan, E.; van Veen, A.C.; Mirodatos, C.; Shen, W. Hydrogen production from ethanol over $\mathrm{Ir} / \mathrm{CeO}_{2}$ catalysts: A comparative study of steam reforming, partial oxidation and oxidative steam reforming. J. Catal. 2008, 257, 96-107. [CrossRef]

31. Wang, F.; Cai, W.; Provendier, H.; Schuurman, Y.; Descorme, C.; Mirodatos, C.; Shen, W. Hydrogen production from ethanol steam reforming over $\mathrm{Ir} / \mathrm{CeO}_{2}$ catalysts: Enhanced stability by PrOx promotion. Int. J. Hydrog. Energy 2011, 36, 13566-13574. [CrossRef] 
32. Zhang, B.; Tang, X.; Li, Y.; Xu, Y.; Shen, W. Hydrogen production from steam reforming of ethanol and glycerol over ceria-supported metal catalysts. Int. J. Hydrog. Energy 2007, 32, 2367-2373. [CrossRef]

33. Cai, W.; Wang, F.; Daniel, C.; van Veen, A.C.; Schuurman, Y.; Descorme, C.; Provendier, H.; Shen, W.; Mirodatos, C. Oxidative steam reforming of ethanol over $\mathrm{Ir} / \mathrm{CeO}_{2}$ catalysts: A structure sensitivity analysis. J. Catal. 2012, 286, 137-152. [CrossRef]

34. Fleming, P.; Farrell, R.A.; Holmes, J.D.; Morris, M.A. The Rapid Formation of $\mathrm{La}(\mathrm{OH})_{3}$ from $\mathrm{La}_{2} \mathrm{O}_{3}$ Powders on Exposureto Water Vapor. J. Am. Ceram. Soc. 2010, 93, 1187-1194. [CrossRef]

35. Said, A.E.-A.A.; El-Wahab, M.M.M.A.; El-Aal, M.A. Catalytic dehydration of methanol to dimethyl ether over nanosized $\mathrm{WO}_{3} / \mathrm{Al}_{2} \mathrm{O}_{3}$ system under inert and oxidative atmosphere. Chem. Mon. 2016, 147, 1507-1516. [CrossRef]

36. Thyssen, V.V.; Maia, T.A.; Assaf, E.M. Ni supported on $\mathrm{La}_{2} \mathrm{O}_{3}-\mathrm{SiO}_{2}$ used to catalyze glycerol steam reforming. Fuel 2013, 105, 358-363. [CrossRef]

37. Atanasoska, L.; Gupta, P.; Deng, C.; Warner, R.; Larson, S.; Thompson, J. XPS, AES, and Electrochemical Study of Iridium Oxide Coating Materials for Cardiovascular Stent Application. ECS Trans. 2009, 16, 37-48. [CrossRef]

38. XPS Simplified. Available online: http://xpssimplified.com/elements/nickel.php (accessed on 5 April 2018).

39. Sunding, M.F.; Hadidi, K.; Diplas, S.; Løvvik, O.M.; Norby, T.E.; Gunnæs, A.E. XPS characterisation of in situ treated lanthanum oxide and hydroxide using tailored charge referencing and peak fitting procedures. J. Electron Spectrosc. Relat. Phenom. 2011, 184, 399-409. [CrossRef]

40. Lebugle, A.; Axelsson, U.; Nyholm, R.; Mårtensson, N. Experimental L and M Core Level Binding Energies for the Metals ${ }^{22} \mathrm{Ti}$ to ${ }^{30} \mathrm{Zn}$. Phys. Scr. 1981, 23, 825. [CrossRef]

41. Miller, A.C.; Simmons, G.W. Nickel by XPS. Surf. Sci. Spectra 1992, 1, 312-317. [CrossRef]

42. Kašpar, J.; Fornasiero, P.; Graziani, M. Use of $\mathrm{CeO}_{2}$-based oxides in the three-way catalysis. Catal. Today 1999, 50, 285-298. [CrossRef]

43. Yao, H.C.; Yao, Y.F.Y. Ceria in automotive exhaust catalysts: I. Oxygen storage. J. Catal. 1984, 86, $254-265$. [CrossRef]

44. Harrison, B.; Diwell, A.F.; Hallett, C. Promoting Platinum Metals by Ceria. Platin. Met. Rev. 1988, 32, 73-83.

45. Jha, A.; Jeong, D.-W.; Jang, W.-J.; Rode, C.V.; Roh, H.-S. Mesoporous $\mathrm{NiCu}-\mathrm{CeO}_{2}$ oxide catalysts for high-temperature water-gas shift reaction. RSC Adv. 2015, 5, 1430-1437. [CrossRef]

46. Chen, H.; Yu, H.; Tang, Y.; Pan, M.; Yang, G.; Peng, F.; Wang, H.; Yang, J. Hydrogen production via autothermal reforming of ethanol over noble metal catalysts supported on oxides. J. Nat. Gas Chem. 2009, 18, 191-198. [CrossRef]

47. González-Cortés, S.L.; Orozco, J.; Moronta, D.; Fontal, B.; Imbert, F.E. Methane Conversion Over $\mathrm{Sr}^{2+} / \mathrm{La}_{2} \mathrm{O}_{3}$ Catalyst Modified with Nickel and Copper. React. Kinet. Catal. Lett. 2000, 69, 145-152. [CrossRef]

48. Dokjampa, S.; Rirksomboon, T.; Phuong, D.T.M.; Resasco, D.E. Ring opening of 1,3-dimethylcyclohexane on Ir catalysts: Modification of product distribution by addition of $\mathrm{Ni}$ and $\mathrm{K}$ to improve fuel properties. J. Mol. Catal. A Chem. 2007, 274, 231-240. [CrossRef]

49. Guo, Y.; Wan, T.; Zhu, A.; Shi, T.; Zhang, G.; Wang, C.; Yu, H.; Shao, Z. Performance and durability of a layered proton conducting solid oxide fuel cell fueled by the dry reforming of methane. RSC Adv. 2017, 7, 44319-44325. [CrossRef]

50. Shi, R.; Wang, F.; Tana; Li, Y.; Huang, X.; Shen, W. A highly efficient Cu/La $\mathrm{O}_{3}$ catalyst for transfer dehydrogenation of primary aliphatic alcohols. Green Chem. 2010, 12, 108-113. [CrossRef]

51. Wen, G.; Xu, Y.; Ma, H.; Xu, Z.; Tian, Z. Production of hydrogen by aqueous-phase reforming of glycerol. Int. J. Hydrog. Energy 2008, 33, 6657-6666. [CrossRef]

52. Guo, Y.; Liu, X.; Azmat, M.U.; Xu, W.; Ren, J.; Wang, Y.; Lu, G. Hydrogen production by aqueous-phase reforming of glycerol over Ni-B catalysts. Int. J. Hydrog. Energy 2012, 37, 227-234. [CrossRef]

53. Ni, J.; Chen, L.; Lin, J.; Schreyer, M.K.; Wang, Z.; Kawi, S. High performance of Mg-La mixed oxides supported Ni catalysts for dry reforming of methane: The effect of crystal structure. Int. J. Hydrog. Energy 2013, 38, 13631-13642. [CrossRef]

54. Han, X.; Chu, W.; Ni, P.; Luo, S.-Z.; Zhang, T. Promoting effects of iridium on nickel based catalyst in ammonia decomposition. J. Fuel Chem. Technol. 2007, 35, 691-695. [CrossRef] 
55. Manfro, R.L.; da Costa, A.F.; Ribeiro, N.F.P.; Souza, M.M.V.M. Hydrogen production by aqueous-phase reforming of glycerol over nickel catalysts supported on $\mathrm{CeO}_{2}$. Fuel Process. Technol. 2011, 92, 330-335. [CrossRef]

56. Luo, N.; Fu, X.; Cao, F.; Xiao, T.; Edwards, P.P. Glycerol aqueous phase reforming for hydrogen generation over Pt catalyst-Effect of catalyst composition and reaction conditions. Fuel 2008, 87, 3483-3489. [CrossRef] 